\title{
Use of certain herbal preparations in broiler feeds - A review
}

\author{
Tirupathi Reddy Eevuri and Ramya Putturu
}

College of Veterinary Science,

Sri Venkateswara Veterinary University, Rajendranagar, Hyderabad-30, India

Corresponding author: Tirupathi Reddy Eevuri, e-mail: tiruvety@gmail.com

Received: 21-06-2012, Accepted: 14-07-2012, Published online: 27-12-2012

\section{How to cite this article:}

Eevuri TR and Putturu R (2013) Use of certain herbal preparations in broiler feeds - A review, Vet World, 6(3): 172-179, doi: 10.5455/vetworld.2013.172-179

\begin{abstract}
The importance and use of herbal remedies (turmeric, tulsi, amla and aloe vera etc.) has been reviewed systematically. Turmeric (curcumin), acts as an antioxidant, antimutagenic, antiinflamatory and antimicrobial agent and protect liver against a variety of toxicants. Tulsi (eugenol) have anticancer properties, reduced blood glucose levels, total cholesterol levels and promotes immune system function. Amla, richest source of vitamin-c and it's active tannoid principles have antimicrobial, antidiabetics, anticarcinogenic properties and enhances immune property. Aloe vera contains phytochemicals (Saponins, flavonoids, alkaloids and phenols), which is an indication of cosmetic and medicinal value. Turmeric, tulsi, amla and aloe vera preparations increased the body weight gain, feed efficiency and decreased the feed intake. These preparations decreased the mortality rates and the cost of feed has been decreased from $6.2 \%$ to $13.5 \%$. They have reduced the fat accumulation, increased dressing percentage, liver weight, spleen weight and whole giblet weights. Significant reduction of serum cholesterol, serum triglycerides and increased the humoral response against RD vaccine.
\end{abstract}

Keywords: broiler, carcass trait, herbal, immune response, production parameters

\section{I ntroduction}

The existing conventional disease control programs favor the high investment intensive systems of production with birds in confinement and not smallscale farmers with less than 100 birds. Since ancient times, plants and plant parts have an indispensable source of medicine for indigenous poultry production systems. Although modern medical science has developed to a great extent, many farmers depend on plant parts and herbal remedies for indigenous poultry health management. Unfortunately, local medical traditions are being lost because they are communicated orally from generation to generation and are largely undocumented. Very little has been done to verify and validate information gathered. Even today the WHO estimates that upto $80 \%$ of people still rely on traditional remedies such as herbs for their medicine [1].

Specific concoctions were prepared for specific diseases. For example Aloe Vera was said to prevent Newcastle, Croton megalocarpus to treat coryza sinusitis, and combretum mole to treat intestinal worms. Pepper (capsicum), Khasanda kwata, imbululusi concoctions were used respiratory diseases, Sisal (Likonge), Omusirangokho, tithonia concoctions for gastrointestinal ailments, neem (Azadirachta indica) was known to prevent viral ailments [2].

Extracts of Aloe spp, Lilokha, Mondia whytei and Azandrachta indica exhibited significant antimicrobial activities against Salmonella tymphi, Staphylococcus aureus andEscherichia Coli whereas the extracts of Imbululusi exhibited antimicrobial activities against
Salmonella Typhi and Staphylococcus aureus [2].

Aloe spp was the most commonly used herb in rural poultry management [3] as it was used in management of a variety of diseases and Aloe acted as broad spectrum remedy [4] in rural poultry health management. Aloevera used for human health for variety of symptoms. Eventhough there is little or no scientific evidence justifying anecdotal claims [5].

\section{Turmeric (Curcuma longa)}

Turmeric (Curcuma longa) is a rhizomatous herbaceous perennial plant of the ginger family, Zingiberaceae [6] with medicinal properties known to possess antimicrobial and anti-oxidant properties. It is native to tropical South Asia and needs temperatures between $20^{\circ} \mathrm{C}$ and $30^{\circ} \mathrm{C}$ and a considerable amount of annual rainfall to thrive [7]. Rhizome is the portion of medicinal importance and is usually boiled, cleaned, dried and powdered before usage [8]. In medieval Europe, turmeric became known as Indian saffron, since it was widely used as an alternative to the far more expensive saffron spice. Turmeric is commonly called "Pasupu" in Telugu, Kaha in Sinhala, Manjal in Tamil, "Arisina" in Kannada, "Haridra" in Sanskrit and haldar or Haldi in Hindi.

Composition: Dried turmeric contains $6.3 \%$ protein, $5.1 \%$ fat, $3.5 \%$ minerals, $69.4 \%$ carbohydrates and $13.1 \%$ moisture [9]. Turmeric contains up to $5 \%$ essential oils and up to 5\% curcumin, a polyphenol. Curcumin is the active substance of turmeric which is known as C.I. 75300 , or Natural Yellow 3. The systematic chemical name is $(1 E, 6 E)-1,7$-bis(4-hydroxy-3-methoxy- 
phenyl)-1,6-heptadiene-3,5-dione. The active ingredients of turmeric were tetrahydro curcuminoids, curcumin, dimethoxy curcumin and bismethoxy curcumin $[10$, 11].

Uses: The continuing research indicates that turmeric and its active compound "Curcumin" are unique antioxidants, antimutagenic, antitumorigenic, anticarcinogenic, anti-inflammatory, antiarthritis, antimicrobial and hypocholesterolemic properties $[12,13]$. Therapeutic properties of turmeric includes anti-oxidant, anti-diabetic, antibacterial, antifungal, antiprotozoal, antiviral and hypocholesteremic activities [14,15].

Turmeric is currently being investigated for possible benefits in Alzheimer's disease [16], cancer [17], arthritis, and other clinical disorders [18,19]. As an example of preliminary laboratory research, turmeric ameliorated the severity of pancreatitis - associated lung injury in mice [20].

Turmeric and curcumin have been shown to protect liver against a variety of toxicants including carbon tetrachloride, aflatoxin $\mathrm{B}_{1}$ and cyclophosphamide in mouse, rat and duckling [21]. The curcuminoids (yellowish pigments) present in turmeric powder have shown protective effect against aflatoxin $B_{1}$ [22]. The traditional usage of turmeric in various conditions like biliary disorders, anorexia, cough, diabetes, wounds, hepatic disorders, rheumatism and sinusitis [23]. Kirtikar and Basu [24] reported that Rhizome is also used as carminative, diuretic, hepatoprotective and in treatment of urinary tract and skin diseases like scabies, leech bites and bruises.

\section{Tulsi (Ocimum tenuiflorum)}

Ocimum tenuiflorum, Holy Basil (also Tulsi, tulas $\vec{\imath}$ ), is an aromatic plant in the family Lamiaceae, which is native throughout the Old World tropics and widespread as a cultivated plant and an escaped weed [25]. The two main morphotypes cultivated in India and Nepal are green-leaved (Sri or Lakshmi Tulsi) and purple-leaved (Krishna Tulsi) [26].

Composition: Prakash and Gupta [27] reported that tulsi contains eugenol (1-hydroxy 2-methoxy 4 allyl benzene) a phenolic compound and ursolic acid having pharmacological effects. Some of the main chemical constituents of Tulsi are: oleanolic acid, ursolic acid, rosmarinic acid, eugenol, carvacrol, linalool, $\beta$-caryophyllene [28], $\beta$-elemene (c.11.0\%), $\beta$-caryophyllene (about 8\%), and germacrene D (about 2\%) [29]. $\beta$ Elemene has been studied for its potential anticancer properties [30] but human clinical trials have yet to confirm its effectiveness.

Uses: It is an effective treatment for reducing blood glucose levels [31] and total cholesterol levels [32]. Tulsi also shows some promise for protection from radiation poisoning [33] and cataracts [34]. The fixed oil has demonstrated antihyperlipidemic and cardioprotective effects in rats fed a high fat diet [35]. Experimental studies have shown an alcoholic extract of Tulsi modulates immunity, thus promoting immune system function [36]. O. sanctum extracts are antibacterial against $E$. coli, S. aureus and P. aeruginosa) [37,38].

Tulsi is a well known therapeutic agent for several pathological conditions possess antistress [39] and antioxidant [40] properties. An important sacred medicinal herb from India has been known to possess remarkable biological activities like antimicrobial, immunomodulatory, anti cancerous, anti oxidant, anti inflammatory, hepatoprotective [40] and cardioprotective etc. [41]. Prakash and Gupta [27] reported that other therapeutic potential actions of tulsi includes antifungal [42], antispasmodic, antiemetic, analgesic, hypolipidemic and antiviral also. Furthermore, tulsi could inhibit the lipid peroxidation [43].

Tulsi is considered to be an adaptogen [28], balancing different processes in the body, and helpful for adapting to stress. Marked by its strong aroma and astringent taste, it is regarded in Ayurveda as a kind of "elixir of life" and believed to promote longevity [44]. Tulsi extracts are used in ayurvedic remedies for common colds, headaches, stomach disorders, inflammation, heart disease, various forms of poisoning, and malaria. Traditionally, tulsi is taken in many forms: as herbal tea, dried powder, fresh leaf, or mixed with ghee. Essential oil extracted from Karpoora Tulsi is mostly used in skin preparations due to its antibacterial activity. The dried leaves have been mixed with stored grains to repel insects [45].

Tulsi is a sacred plant for Hindus and is worshipped by Hindus as the avatar of goddess Lakshmi and plants are grown infront of or near their home. Water mixed with the petals is given to the dying to raise their departing souls to heaven [46]. The ritual lighting of lamps each evening during Kartika includes the worship of the tulsi plant, which is held to be auspicious for the home. Vaishnavas traditionally use japa malas made from tulsi stems or roots, which are an important symbol of initiation. Tulsi malas are considered to be auspicious for the wearer, and believed to put them under the protection of Hanuman.

\section{Amla (Phyllanthus emblica)}

Phyllanthus emblica (syn. Emblica officinalis), the Indian gooseberry, or aamla, is a deciduous tree of the Phyllanthaceae family and is known for its edible fruit. Common name of this tree include Usiri (in Telugu), Nellikai (in Tamil and Kannada).

Composition: Amla powder contains 5.05 to 6.78 per cent moisture, 0.23 to 0.59 per cent fat and minerals like Calcium 79.6mg, Phosphorous $12.38 \mathrm{mg}$ and Iron $88.03 \mathrm{mg} / 100 \mathrm{~g}$ [47]. Amla is one of the richest sources of Vit-C and contains 700mg [48]. In addition to this several active tannoid principles (Emblicanin A, Emblicanin B, Punigluconin and pedunculagin) have been identified for their health benefits [49].

Uses: Medical studies conducted on Amla fruit suggest that it has anti-viral properties [50] and also functions 
as an anti-bacterial and anti-fungal agent [51]. Amla has been particularly indicated for anemia, asthma, bleeding gums, diabetes, chronic lung disease, hyperlipidaemia, yeast infections, scurvy and cancer $[52,53]$. Amla has been known in Ayurvedic medicine for its tonifying, anti-ageing and immune enhancing properties [54]. Animals fed on amla powder showed better ability for uptake and killing of bacteria, which might be due to the presence of tannins which stimulates phagocytic cells [55].

Indian gooseberry has undergone preliminary research, demonstrating in vitro antiviral [50] and antimicrobial properties [56]. There is preliminary evidence in vitro that its extracts induce apoptosis and modify gene expression in osteoclasts involved in rheumatoid arthritis and osteoporosis [57]. It may prove to have potential activity against some cancers [58]. One recent animal study found treatment with $E$. of? cinalis reduced severity of acute pancreatitis (induced by L-arginine in rats). It also promoted the spontaneous repair and regeneration process of the pancreas occurring after an acute attack [59]. Experimental preparations of leaves, bark or fruit have shown potential efficacy against laboratory models of disease, such as for inflammation [60,61], cancer, agerelated renal disease, and diabetes [62].

A human pilot study demonstrated a reduction of blood cholesterol levels in both normal and hypercholesterolemic men with treatment [63]. Another recent study with alloxan-induced diabetic rats given an aqueous amla fruit extract has shown significant decrease of the blood glucose, as well as triglyceridemic levels and an improvement of the liver function caused by a normalization of the liver-specific enzyme alanine transaminase activity [64].

It has antioxidant property eventhough it has high density of tannins [65]. The fruit also contains other polyphenols: flavonoids, kaempferol, ellagic acid and gallic acid [66].

According to Ayurveda, aamla fruit is sour ( $\mathrm{amla}$ ) and astringent (kashaya) in taste (rasa), with sweet (madhura), bitter (tikta) and pungent (katu) secondary tastes (anurasas) [66] and all parts are used in ayurveda/unani medicines. Balances both Pitta and vata by virtue of its sweet taste. It may be used as a rasayana (rejuvenative) to promote longevity, and traditionally to enhance digestion (dipanapachana), treat constipation (anuloma), reduce fever (jvaraghna), purify the blood (raktaprasadana), reduce cough (kasahara), alleviate asthma (svasahara), strengthen the heart (hrdaya), benefit the eyes (chakshushya), stimulate hair growth (romasanjana), enliven the body (jivaniya), and enhance intellect (medhya) [66,67]. Indian gooseberry is a common constituent, and most notably is the primary ingredient in an ancient herbal rasayana called Chyawanprash [68]. Emblica officinalis tea may ameliorate diabetic neuropathy.

\section{Aloe vera (Aloe barbadensis)}

The botanical name of aloe vera is Aloe barbadensis miller. It belongs to Asphodelaceae (Liliaceae) family, and is shrubby, or absorescent, perennial, xerophytic, succulent, pea-green color plant. It has long triangular, fleshy leaves that have spikes along the edges. The fresh parenchymal gel from the centre of the leaf is clear, this part is sometimes dried to form aloevera concentrate or diluted with water to treate aloe juice products. The sticky latex liquid is derived from the yellowish green pericyclic tubules that line the leaf (rind): this is the part that yields laxative anthraquinones [69]. Aloes are indigenous to south Africa and South America, but are now cultivated worldwide except in tundra deserts and rainy forests. In the US Aloe is commercially cultivated in southern Texas [70].

Composition: Dried aloe contains $73.07 \%$ carbohydrates, $4.73 \%$ protein, $0.27 \%$ fat an trace amounts of tannins $(0.155 \% \mathrm{~g} / 100 \mathrm{~g})$, oxalate $(0.68 ` 3 \mathrm{~g} / 100 \mathrm{~g})$ and Phytate $(0.54 \mathrm{~g} / 100 \mathrm{~g})$. Aloe vera contains phytochemicals like saponins $(5.651 \mathrm{~g} / 100 \mathrm{~g})$, flavanoids $(3.246 \mathrm{~g} / 100 \mathrm{~g})$, alkaloids $(2.471 \mathrm{~g} / 100 \mathrm{~g})$ and phenols $(0.232 \mathrm{~g} / 100 \mathrm{~g}) \mathrm{phenols}$, which is an indicative of cosmetic and medicinal value of Aloe barbadensis. It is also rich in minerals like $\mathrm{Na}, \mathrm{K}, \mathrm{P}$, and $\mathrm{Mg}$ [71].

Uses: Aloe vera may be effective in treatment of wounds [72] and it also promotes the rate of wound healing [73]. Topical application of aloe vera may also be effective for genital herpes and psoriasis [72]. Aloe vera extracts may be useful in the treatment of diabetes and elevated blood lipids in humans [4] which is due to the presence of compounds such as mannans, anthraquinones and lectins.

Aloe extracts are useful in treatment of hyperglycemia [74], hyperlipemia [75], but also with acute hepatitis [76]. Preliminary studies have suggested that oral aloe vera gel may reduce symptoms and inflammation in patients with ulcerative colitis [77]. Aloe vera extracts have been used as immunostimulant that aids in fighting cancers in cats and dogs [78]. Extracts of aloe vera might have anti-bacterial and anti-fungal activities which possibly could help to treat minor skin infections such as boils, benign skin cysts and may inhibit growth of fungi causing tinea [79]. Juice from the pulp is useful for treating jaundice, menustrual disorders, scalp disorders, skin diseases, burns and haemorrhoids [80]. Moghadassi and Verma, [81] has reviewed that it is useful for skin damaged from $\mathrm{X}$ rays. On other hand concentration of glucose in gelatin results in high osmotic pressure that protects skin from live bacteria. Aloe vera includes antrokinone chemicals that are known for anti-virus, anti-bacterial and anticancer properties.

\section{Effect of herbal preparation on body w eight gain}

Better growth rates in broilers by inclusion of powdered rhizome of Curcuma longa @ 1g/kg diet [82] and @ $0.5 \%$ [83]. Improved body weight gain observed in broilers by inclusion of turmeric powder @ 0.75-1\% 
in diet [84] and 444 ppm [13]. Higher gain in body weights of broilers were observed @ 6.2 and 15.1 per cent respectively by addition of turmeric at 2 and $3 \mathrm{~g} / \mathrm{kg}$ feed in broilers [85] and $0.5 \%$ has resulted $6 \%$ extra weight gain [10]. Weight gains also observed in broilers affected with aflatoxin [86] and E.acervulina [87]. Namagirilakshmi [88] observed insignificant body weight gain in broilers with diet supplementation of turmeric powder, whereas El-Hakim et. al., [89] observed no effect in body weight gain.

Significant increase in body weights of broilers were observed with supplementation of Ocimum sanctum leaves [90,91], whereas, Varaprasad Reddy et al. [92] observed insignificant body weight gain in broilers by inclusion of Tulsi. Gupta and Charan [93] included tulsi powder ranging from $0-600 \mathrm{mg} / \mathrm{kg}$ diet and reported maximum weight gain in broilers was observed with $200 \mathrm{mg} / \mathrm{kg}$ of diet. A combination of aloe vera and curcuma longa [94] resulted no significant difference in body weights of broilers, whereas a combination of amla, Tulsi and turmeric in broiler diets has resulted significant higher body weight gains in broilers [95].

\section{Effect of herbal preparation on feed intake}

Increased feed consumption in broilers was observed by supplementation of diet with powdered rhizome of Curcuma longa @ 1g/kg [96], and @ 0.75$1 \mathrm{~g} / \mathrm{kg}$ [84] whereas $5 \%$ reduction in feed intake was observed by Al-sultan [10] and Gowda et. al., [13]. Significantly lower feed intake was observed by Durrani et. al., [83] with turmeric supplementation in broiler diet, whereas El-Hakim [89] observed no effect on feed intake. Apparently reduction of feed intake in broilers was observed with supplementation of Tulsi leaf powder [91]. A combination of Aloe vera and Curcuma longa in broilers diet has resulted insignificant difference in feed intake [94]. A combination of Amla, Tulsi and Turmeric $(0.25 \%, 0.5 \%)$ in broilers diet has significantly increased feed intake in broilers [95].

\section{Effect of herbal preparation on feed efficiency (FCR)}

Pande, [97] observed significant $(\mathrm{P}<0.01)$ improvement in feed efficiency of broilers with the supplementation of polyherbal preparations containing tulsi as an integral part of Composition. Similar results were reported by Lanjewar et. al., [91] with $1 \%$ inclusion. Turmeric powder inclusion $(0.75 \%-1 \%)$ has improved FCR in broilers $[15,84]$. Supplementation of turmeric powder at the rate of 0.5 per cent level resulted in better feed efficnecy of 1.2 and 2.0 in starter and finisher phase respectively [83], 1.6 [88] and 2.08 [10]. Low level of turmeric $(0.1 \%)$ also had better feed efficiency in broilers [96]. FCR was not effected significantly by inclusion of turmeric extract in broilers $[89 ; 98]$ and in Rabbits [99]. Significant feed conversion ratio was observed by inclusion of Aloe vera and Curcuma longa in broilers [94]. Broilers fed with Amla, Tulsi and
Turmeric either alone or in combination @ $0.25 \%$ and $0.5 \%$ levels resulted in better feed efficiency [95].

\section{Effect of herbal preparation on mortality pattern}

No mortality upto 35 days of age in broilers was observed when turmeric was supplemented at 0.5 per cent level in broiler diet [83] and less mortality was observed @ 0.1\% inclusion[82]. Supplementation of amla and turmeric powder @ $5 \mathrm{~g} / \mathrm{kg}$ of feed in broiler diet resulted no mortality in broilers [100] and less mortality by inclusion of amla, Tulsi and turmeric @ 0.25 and $0.5 \%$ [95]. Less mortality was observed in broiler fed with herbal growth promoter containing amla as one of the ingredients [101]. Hundred per cent livability was observed with inclusion of Aloe vera and Curcuma longa and their combination in broiler diets [94].

\section{Economics of herbal preparations supplemen- tation}

Inclusion of turmeric powder @ $0.5 \%$ in ration of broilers has substantially decreased the feed cost per unit live body weight gains i.e. $13.5 \%$ [82], 11.8\% Durrani et al [83] and 6.2\% Namagirilakshmi [88] compared to control rations. A combination of Aloe vera and Curcuma longa inclusion in broiler diets has resulted significant difference in the feed cost per unit live body weight in the broiler weights up to six weeks of age [94]. Tirupathi Reddy et al. [95] reported a reduction of $4 \%$ feed cost per unit live weight gain in broilers with feed supplemented with combination of amla, tulsi and turmeric @ 0.25\%.

\section{Effect of herbal preparation on carcass traits}

A reduction of fat percentage at $1 \%$ [10] and 1.2\% [85] over body weights were reported by inclusion of turmeric powder in broiler ration. Significant decrease in abdominal fat (57\%) was observed by Emadi \& Kermanshahi [102] by inclusion of turmeric rhizome powder $(0.75 \%)$ in broiler rations. Higher dressing percent i.e. 57\% $[83,103]$ was observed when broilers fed with feed supplemented with turmeric powder. Inclusion of turmeric powder also increased the liver weight [103], spleen weight [10] and whole giblets weight [83]. Tulsi leaf product supplementation in broiler rations has shown insignificant in the weights of liver, bursa and spleen [93].

A combination of amla and turmeric powder (@ $5 \mathrm{~g} / \mathrm{Kg}$ feed) in broiler diet has improved the dressing percentage [100], whereas a combination of aloevera and curcuma longa at various levels has not shown significant difference in abdominal fat, breast muscle weights [104]. A combination of amla, tulsi , and turmeric (@0.5\%) has no significant effect on giblet weights and ready to cook yield percentage [95].

\section{Effect of herbal preparation on serum biochemical constituents}

Supplementation of broiler diets with tulsi leaf powder had insignificant on cholesterol concentration 
[88], whereas a significant increase in serum HDL, cholesterol in laying hens was reported by Deshpande [105]. The levels of liver enzymes (ALT \& ALP) were substantially reduced by feeding broilers with diet supplemented with turmeric powder [106] and Tulsi leaf powder [107]. Supplementation of Tulsi leaf powder in feeds containing aflatoxins had significantly reduced AST, ALT, and ALP enzyme activities [108].

Significant reduction of total serum cholesterol, serum LDL cholesterol and serum triglycerides was observed in broilers fed with tulsi leaf powder supplementation [91]. Lower SGOT levels in serum was obtained in broilers fed with tulsi supplemen-tation, whereas no significant difference in SGPT, uric acid, and creatinine [93].

Supplementation of broiler diet with amla has resulted in lower cholesterol, higher SAP, higher SGPT and normal SGOT in broilers [101]. Varaprasad Reddy [92] reported significant decrease in lipid peroxidation levels and increase in GSH levels in plasma in broilers fed with tulsi leaf powder $(0.5 \%)$ along with Selenium $(0.3 \mathrm{ppm})$. No significant difference was observed in broilers fed with combination of Aloe vera \& Curcuma longa or serum glucose, total cholesterol, HDL, LDL and triglyceride levels. Tirupathi Reddy et al [95] observed no effect on SGOT, SGPT and serum cholesterol with supplementation of amla, tulsi and turmeric powder in different combinations.

\section{Effect of herbal prepations on immune response}

Feeding of broilers on diet supplemented with Curcuma longa $(1 \mathrm{~g} / \mathrm{kg})$ has increased humoral response against RD vaccine tested by HA and HI tests [96]. Emadi and Kermanshahi [109] reported increased immunoglobulins $\operatorname{Ig} \mathrm{A}, \operatorname{IgM}, \operatorname{IgG}$ and decrease in ratio of monocytes in broilers fed with turmeric rhizome powder. Increased HI titre values against New Castle disease was observed with aloe vera whereas decreased value with turmeric feeding in broilers [104]. Combination of amla and Tulsi in broiler diet improved the antibody titres against Newcastle disease [110]. Feeding of broilers with diet supplemented with amla, Tulsi and turmeric powder either alone or in combination resulted in high $\mathrm{HI}$ titre values to ND vaccination [95]. Sawale et. al., [111] recorded increased $\mathrm{HI}$ titres in laying hens treated with herbo mineral toxin binder containing Curcuma longa. High antibody titre was observed in turmeric fed broilers challenged with EtMIC 2, an apical complex protein which place an important role in host cell invasion of Eimeria parasites [87].

\section{References}

1. Arunkumar, S. and Muthuselvam, M. (2009) Analysis of phytochemical constituents and antimicrobial activities of Aloe vera L. against clinical pathogens. World J. Agric. Sci., 5: 572-576.

2. Okitoi, L.O., Ondwasy, H.O., Siamba, D.N. and Nkurumah, D. (2007) Traditional herbal preparations for indigenous poultry health management in Western Kenya. Livestock Research for Rural Development., 19(5).
3. Mwale, M., Bhebhe, E., Chimonyo, M. and Halimani, T.E. (2005) Use of herbal plants in poultry health management in the Mushagashe small-scale commercial farming are in Zimbabwe. International Journal of Applied Research on Veterinary Medicine. 3(2):163-170.

4. Boudreau, M.D. and Beland, F.A. (2006) An evaluation of the biological and toxicological properties of Aloe barbadensis (miller), Aloe vera. J Environ Sci Health C Environ Carcinog Ecotoxicol Rev., 24(1): 103-54.

5. Botes, L., F.H., Van der Westhuizen and D.T. Loots, D.T. (2008) Phytochemical contents and antioxidant capacities of two Aloe greatheadii variants davyana. Extracts., 13: 2169-2180.

6. Chan, E.W.C., Lim, Y., Wong, S., Lim, K., Tan, S., Lianto, F. and Yong, M. (2009) Effects of different drying methods on the antioxidant properties of leaves and tea of ginger species. Food Chemistry., 113(1):166-172.

7. Materia Indica. (1826) Whitelaw Ainslie, M.D. M.R.A.S., via Google Books.

8. Anonymous. (2001) Turmeric (Curcuma longa) monograph. Alternative Medicine Review., 6:62-66.

9. Chattopadhyay, I., Biswas, K., Bandyopadhyay, U. and Banerjee. R.K. (2004) Turmeric and Curcumin: biological actions and medicinal applications. Current Science., 87:4453.

10. Al-Sultan, S.I. (2003) The effect of Curcuma longa (turmeric) on overall performance of broiler chickens. International Journal of Poultry Science., 2:354-53.

11. HMPC (Committee on Herbal Medicinal Products). (2009) Assessment Report on Curcuma Longa L. Rhizoma. European Medicines Agency.

12. Miquel, J., Bernd, A., Sempere, J.M. and Diaz-Alperi J., Ramirez, A. (2002) Curcuma antioxidants: pharmacological effects and prospects future clinical use. A review Archives of Gerontology and Geriatrics., 34:37-46.

13. Gowda, N.K.S., Ledoux, D.R., Goerge, E.R., Bermudez, A.J. and Chen, Y.C. (2009) Antioxidant efficacy of curcuminoids from turmeric (Curcuma longa L.) powder in broiler chickens fed diets containing aflatoxin B1. British Journal of Nutrition., 102: 1629-1634.

14. Abbas, R.Z., Iqbal, Z., Khan, M.N., Zafar, M.A. and Zia, M.A. (2010) Anticoccidial activity of curcuma longa L. in broilers. Brazilian Archives of Biology and Technology., 53: 63-67.

15. Ahmadi, F. (2010) Effect of turmeric powder on performance, oxidative stress state and some of blood parameters in fed on diets containing aflatoxin. Global Veterinaria., 5: 312-317.

16. BBC News. (2001) Curry 'may slow Alzheimer's'. 21 November 2001. Retrieved 28 March 2010.

17. Lin, L.I. and Ke, Y.Fl. (1998) Curcumin inhibits SK-Hep-1 hepatocellular carcinoma cell invasion in vitro and suppresses matrix metalloproteinase-9 secretion. Oncology., 55:349-53.

18. Gregory, P.J., Sperry, M. and Wilson. A.F. (2008) Dietary supplements for osteoarthritis. American Family Physician., 77(2):177-84.

19. Henrotin, Y., Clutterbuck, A.L. and Allaway, D. (2010) Biological actions of curcumin on articular chondrocytes. Osteoarthritis and Cartilage., 18(2):141-49.

20. Seo, S.W., Bae, G.S., Kim, S.G., Yun, S.W., Kim, M.S., Yun, K.J., Park, R.K., Song, H.J. and Park, S.J. (2011) "Protective effects of Curcuma longa against cerulein-induced acute pancreatitis and pancreatitis-associated lung injury". International Journal of Molecular Medicine., 27(1):53-61.

21. Soudamini, K.K. and Kuttan, R. (1992) Inhibition of lipid peroxidation and cholesterol levels in mice by curcumin. Indian Journal of Physiology Pharmacology., 36:239-243.

22. Gowda, N.K.S., Ledoux, D.R., Rottinghaus, G.E., Bermudez, A.J. and Chen, Y.C. (2008) Efficacy of turmeric (curcuma longa), containing a known level of curcumin, and a hydrated sodium calcium aluminosilicate to ameliorate the adverse effects of aflatoxin in broiler chicks. Poultry 
Science., 87: 1125-1130.

23. Ammon, H.P.T. and Wahl, M.A. (1991). Pharmacology of Curcuma longa. Planta Med., 57:1-7.

24. Kirtikar, K.R. and Basu, B.D. (1996). Indian medicinal plants. Vol. IV. International Book Distributors, Dehradun. pp. 2423-25.

25. Staples, George., Michael, S. and Kristiansen. (1999) Ethnic Culinary Herbs. University of Hawaii Press. p. 73.

26. Kothari, S.K. and Bhattacharya. (2005) Volatile Constituents in Oil from Different Plant Parts of Methyl Eugenol-Rich Ocimum tenuiflorum L.f. (syn. O. sanctum L.) Grown in South India. Journal of Essential Oil Research.

27. Prakash, P. and Gupta, N. (2005) Therapeutic uses of Ocimum sanctum Linn (Tulsi) with a note on Eugenol and its pharmacological actions. A short review. Indian Journal of Physiology Pharmacology., 49(2):125-131.

28. Kuhn, Merrily. and David, Winston. (2007) Winston \& Kuhn's Herbal Therapy \& Supplements. A Scientific and Traditional Approach., Lippincott Williams \& Wilkins. p.260.

29. Padalia, Rajendra, C., Verma, Ram, S. (2011) Comparative volatile oil composition of four Ocimum species from northern India. Natural Product Research., 25(6):569-75.

30. Qimgdi, Q. Li., Gangduo, Wang., Manchao, Zhang., Christopher, F., Cuff, Lan, Huang, Eddie, Reed. (2009) BElemene, a novel plant-derived antineoplastic agent, increases cisplatin chemosensitivity of lung tumor cells by triggering apoptosis. Oncology Reports., 22:161-170.

31. Rai, V., Mani, U.V., Iyer, U.M. (1997) Effect of Ocimum sanctum Leaf Powder on Blood Lipoproteins, Glycated Proteins and Total Amino Acids in Patients with Non-insulindependent Diabetes Mellitus. Journal of Nutritional and Environmental Medicine., 7(2):113-18.

32. Suanarunsawat, T., Ayutthaya, W.D.A. and Songsak, T. (2011). Lipid-Lowering and Antioxidative Activities of Aqueous Extracts of Ocimum sanctum L. Leaves in Rats Fed with a High-Cholesterol Diet. Oxidative medicine and cellular longevity., 1-9.

33. Devi, P.U. and Ganasoundari, A. (1999) Modulation of glutathione and antioxidant enzymes by Ocimum sanctum and its role in protection against radiation injury. Indian Journal of Experimental Biology., 37(3): 262-68.

34. Sharma, P., Kulshreshtha, S., Sharma, A.L. (1998) Anticataract activity of Ocimum sanctum on experimental cataract. Indian Journal of Pharmacology., 30 (1):16-20.

35. Suanarunsawat, T., Boonnak, T., Na, Ayutthaya, W. D., Thirawarapan, S. (2010) Anti-hyperlipidemic and cardioprotective effects of Ocimum sanctum L. fixed oil in rats fed a high fat diet. Journal of Basic and Clinical Physiology and Pharmacology., 21(4): 387-400.

36. Mondal, S., Varma, S., Bamola, V. D., Naik, S. N., Mirdha, B. R., Padhi, M. M., Mehta, N., Mahapatra, S.C. (2011) Double-blinded randomized controlled trial for immunomodulatory effects of Tulsi (Ocimum sanctum Linn.) leaf extract on healthy volunteers. Journal of Ethnopharmacology., 136 (3):452-56.

37. Golshahi, H., Ghasemi, E. and Mehranzade, E. (2011) Antibacterial activity of Ocimum sanctum extract against E. coli, S.aureus and P. aeruginosa. Clinical Biochemistry. Conference: 12th Iranian Congress of Biochemistry, ICB and 4th International Congress of Biochemistry and Molecular Biology, ICBMB Mashhad Iran, Islamic Republic of. Conference Start: 20110906 Conference End: 20110909. Conference Publication: (var.pagings). 44 (13 SUPPL. 1) (pp S352), 2011. Journal: Conference Abstract.

38. Poonam, M. and Sanjay, M. (2011) Study of antibacterial activity of Ocimum sanctum extract against Gram+ve and Gram-ve bacteria. American Journal of Food Technology., 6(4):336-341.

39. Moinuddin, G., Devi, K. and Satish, H. (2011) Comparative Pharmacological Evaluation of Ocimum sanctum and Imipramine for Antidepressant Activity. Latin American Journal of Pharmacy., 30 (3): 435-439.
40. Shukla, S. T., Kulkarni, V. H., Habbu, P. V., Jagadeesh, K. S., Patil, B. S. and Smita, D. M. (2012) Hepatoprotective and antioxidant activities of crude fractions of endophytic fungi of Ocimum sanctum Linn. in rats. Oriental Pharmacy and Experimental Medicine., 12(2): 81-91.

41. Gupta, S.K., Prakash, J. and Srivastava, S. (2002) Validation of claim of Tulsi, Ocimum sanctum Linn. as a medicinal plant. Indian Journal of Experimental Biology., 40(7):76573.

42. Balakumar, S., Rajan, S. and Thirunalasundari, T. (2011). Antifungal activity of Ocimum sanctum Linn. (Lamiaceae) on clinically isolated dermatophytic fungi. Asian Pacific Journal of Tropical Medicine., 4 (8): 654-657.

43. Muralikrishnan, G., Pillai, S.K. and Shakeel, F. (2012) Protective effects of Ocimum sanctum on lipid peroxidation and antioxidant status in streptozocin-induced diabetic rats. Natural Product Research. 26(5): 474-8.

44. Puri. and Harbans, Singh. (2002) Rasayana: Ayurvedic Herbs for Longevity and Rejuvenation. CRC Press, 272-80.

45. Biswas, N.P. and Biswas, A.K. (2005) Evaluation of some leaf dusts as grain protectant against rice weevil Sitophilus oryzae (Linn.). Environment and Ecology., 23(3):485-88.

46. Flood, Gavin D. (2001) The Blackwell companion to Hinduism. Wiley-Blackwell. pp. 331.

47. Poonam, Mishra., Vijeyta, Srivastava., Deepmala, Verma., Chauhan, O.P. and Rai, G.K. (2009) Physico-chemical properties of chekiya variety of Amla (Emblica Officinalis) and effect of different dehydration methods on quality of powder. African Journal of Food Science., 3(10):303-06.

48. Saini, A., Sharma, S. and Chhibber, S. (2008) Protective efficacy of Emblica officinalis against Klebsiella pneumoniae induced pneumonia in mice. Indian Journal of Medical Research., 28:188-193.

49. Kim, H.J., Yokozawat, Kimhy, Tohda, C., Rao, T.P. and Juneja, L.R. (2005). Influence of Amla (Emblica Officinalis Gaertnl) on hypercholesterolemia and lipid peroxidation in cholesterol-fed rats. J Nutr Sci Vitaminol., 51:413-418.

50. Koul, P., Singh, S., Sharma, R. and Gupta, V. K. (2010) An overview of the ayurvedic medicinal plant Phyllanthus amarus for its botanical, phytochemical and biological explorations. Medicinal Plants: Phytochemistry, Pharmacology and Therapeutics., 1:315-329.

51. Treadway. and Linda. (1994) Amla traditional food and medicine. Herbal Gram. The Journal of the American Botanical Council., 31:26.

52. Dwivedi, G.V., Tiwari, R.K., Shanker, K. and Trivedi, V.P. (2003) The management of asthma with single herbs and vasadikwath-an ayurvedic preparation. Medicinal Aromatic Plants Abstract., 25:180.

53. Akhtar, M.S., Ramzan, A., Ali, A. and Ahmad, M. (2011) Effect of Amla fruit (Emblica officinalis Gaertn.) on blood glucose and lipid profile of normal subjects and type 2 diabetic patients. Int J Food Sci Nutr ., 02 (01): 176-183.

54. Lalla, J.K., Hamrapurkar, P.D. and Mamania, H.M. (2001) Triphala churna from raw materials to finished products. Indian Drugs., 38:87-94.

55. SaiRam, M., Neetu, D., Deepti, P., Vandana, M., Ilavazhagan, G. and Kumar, D. (2001) Cytoprotective activity of Amla (Emblica officinalis) against chromicum (VI) induced oxidative injury in murine macrophages. Phytotherapy Research., 17:430-33.

56. Kumar, A., Tantry, B.A., Rahiman, S. and Gupta, U. (2011) Comparative study of antimicrobial activity and phytochemical analysis of methanolic and aqueous extracts of the fruit of Emblica officinalis against pathogenic bacteria. J Tradit Chin Med., 31(3): 246-50.

57. Penolazzi, L. et al. (2008) Induction of apoptosis of human primary osteoclasts treated with extracts from the medicinal plant Emblica officinalis. BMC Complementary and Alternative Medicine., 8:59.

58. Ngamkitidechakul, C., Jaijoy, K., Hansakul, P., Soonthornchareonnon, N., Sireeratawong S. (2010) 
Antitumour effects of Phyllanthus emblica L. induction of cancer cell apoptosis and inhibition of in vivo tumour promotion and in vitro invasion of human cancer cells. Phytotherapy Research., 24(9):1405-13.

59. Sidhu, S., Pandhi, P., Malhotra, S., Vaiphei, K. and Khanduja, K.L. (2011) Beneficial Effects of Emblica officinalis in 1Arginine-Induced Acute Pancreatitis in Rats, Journal of Medicinal Food., 14(1-2):147-155.

60. Dang, G.K., Parekar, R.R., Kamat, S.K., Scindia, A.M. and Rege, N.N. (2011) Antiinflammatory activity of Phyllanthus emblica, Plumbago zeylanica and Cyperus rotundus in acute models of inflammation. Phytother Res., 25(6): 904-908.

61. Sanjeela, G., Nitin, S., Rakshith, G. and Basavaraj, N. (2011) Anti-inflammatory Effect of Amla (Emblica Officinalis) on Plaque Induced Gingivitis - A Clinical Study. JIDA, 5(7): 799-801.

62. Yokozawa, T., Kim, H.Y., Kim, H.J. (2007) Amla (Emblica officinalis Gaertn.) attenuates age-related renal dysfunction by oxidative stress. Journal of Agricultural and Food Chemistry., 55(19):7744-52.

63. Jacob. A., Pandey, M., Kapoor, S. and Saroja, R. (1988) Effect of the Indian gooseberry (amla) on serum cholesterol levels in men aged 35-55 years. European Journal of Clinical Nutrition., 42(11): 939-44.

64. Qureshi, S.A., Asad, W., Sultana, V. (2009) The Effect of Phyllantus emblica Linn on Type-II Diabetes, Triglycerides and Liver-Specific Enzyme. Pakistan Journal of Nutrition., 8(2): $125-28$.

65. Wei, L., Mouming, Z., Bao, Y., Jiaoyan, R., Guanglin, S. and Guohua, R. (2011) Antioxidant and antiproliferative capacities of phenolics purified from Phyllanthus emblica L. fruit . Food chemistry., 126 (1 ): 277-282.

66. Rehman, H.U., Yasin, K.A. and Choudhary, M.A., (2007) Studies on the chemical constituents of Phyllanthus emblic. Natural Product Research., 21(9):775-81.

67. Reddy, V.D., Padmavathi, P., Kavitha, G., Gopi, S. and Varadacharyulu, N. (2011) Emblica officinalis ameliorates alcohol-induced brain mitochondrial dysfunction in rats. $\mathrm{J}$ Med Food., 14(1-2): 62-68.

68. Dharmananda, S. (2003) Emblic Myrobalans: Amla, Key herb of Ayurvedic medicine. Institute of Traditional Medicine, Portland, Oregon.

69. Schulz, V., Hansel, R., Tyler, VE. (1997) Rational Phytotherapy: APhysicians guide to herbal medicine. Berlin: Springer., 306.

70. Foster, S. (1999) Aloe. Herbs for Health., 59-60.

71. Adesuyi, A.O., Awosanya, O.A., Adaramola, F.B. and Omeonu, A.I. (2012) Nutritional and Phytochemical Screening of Aloe barbadensis. Current Research of Journal Biological Sciences., 4(1): 4-9.

72. Vogler, B.K. and Ernst, E. (1999) Aloe vera: a systematic review of its clinical effectiveness. British Journal of General Practice., Oct;49:(447):823-8.

73. Heggers, J.P., Elzaim, H. and Garfield, R. (1997) "Effect of the combination of Aloe vera, nitroglycerin, and L-NAME on wound healing in the rat excisional model". Journal of alternative and complementary medicine., 3 (2): 149-53.

74. Akinmoladun, A.C. and Akinloye, O. (2007) Prevention of the onset of hyperglycaemia by extracts of Aloe barbadensis in rabbits treated with alloxan. African Journal of Biotechnology., 6(8): 1028-1030.

75. Nassiff, H.A., Fajardo, F. and Velez, F. (1993) Effecto del aloe sobre la hiperlipidemia en pacientes refractarios a la dieta. Rev Cuba Med Gen Integr., 9:43-51.

76. Bottenberg., M.M., Wall., G.C., Harvey, R.L. and Habib, S. (2007) Oral aloe vera-induced hepatitis. The Annals of Pharmacotherapy.,41 (10): 1740-3.

77. Langmead, L., Feakins, R.M. and Goldthorpe, S. (2004) Randomized, double-blind, placebo-controlled trial of oral aloe vera gel for active ulcerative colitis. Alimentary Pharmacology \& Therapeutics., 19 (7): 739-47.

78. King, G.K., Yates, K.M. and Greenlee, P.G. (1995) The effect of Acemannan Immunostimulant in combination with surgery and radiation therapy on spontaneous canine and feline fibrosarcomas. Journal of the American Animal HospitalAssociation., 31 (5): 439-47.

79. Shamim, Sumbul,, Ahmed, S., Waseemuddin., Azhar, Iqbal. (2004) Antifungal activity of Allium, Aloe, and Solanum species. Pharmaceutical Biology., 42 (7): 491-498.

80. Mathew, P. (2008) Aloe vera. Natures magic. http:// www. naturesmagic.in/,retrieved on 19-05-2012.

81. Moghaddasi, S.M. and Verma, S.K. (2011) Aloe vera their chemicals composition and applications: A review. Int J Biol MedRes., 2(1): 466-471.

82. Kumar. M., Choudhary, R.S. and Vaishnav. J.K. (2005) Effect of supplemental prebiotic, probiotic and turmeric in diet on the performance of broiler chicks during summer. Indian journal of Poultry Science., 40:137-141.

83. Durrani, F.R., Mohammad, Ismail., Asad, Sultan., Suhail, S.M., Naila, Chand. and Durrani, Z. (2006) Effect of different levels of feed added turmeric (Curcuma longa) on the performance of broiler chicks. Journal of Agricultural Biology Science., 1:9-11.

84. Al-Kassie, G.A.M., Mohseen, A.M. and Abd-Al-Jaleel, R.A. (2011) Modification of productive performance and physiological aspects of broilers on the adition of a mixture of cumin and turmeric to the diet. Research Opinions in animal \& Veterinary Sciences., 1:31-34.

85. Samarasinghe, K., Wenk, C., Silva, K.F.S.T. and Gunasekara, J.M.D.M. (2003). Turmeric (Curcuma longa) root powder and mannanoligosaccharides as alternatives to antibiotics in broiler chicken diet. Asian-Australian Journal of Animal Sciences., 16:1495-1500.

86. Yarru, L.P., Settivari, R.S., Gowda, N.K.S., Antoniou, E., Ledoux, D.R. and Rottinghaus, G.E. (2009) Effects of Turmeric (curcuma longa) on the expression of hepatic genes associated with biotransformation, antioxidant, and immune systems in broiler chicks fed aflatoxin. Poultry Science., 88: 2620-2627.

87. Lee, S.H., Lillehoj, H.S., Jang, S.I., Kim, D.K., Ionescu, C. and Bravo, D. (2010) Effect of dietary Curcuma, capsicum and lentinus on enhancing local immunity against Eimeria acervulina infection. Journal of Poultry Science., 47: 89-95.

88. Namagirilakshmi, S. (2005) Turmeric (Curcuma longa) as nutraceutical to improve broiler performance. M.V.Sc., Thesis submitted to Tamil Nadu Veterinary and Animal Sciences University, Chennai.

89. El-Hakim, A.S.A., Cherian, G. and Ali, M.N. (2009) Use of organic acid, herbs and their combination to improve the utilization of commercial low protein broiler diet. Int. J. Poult. Sci., 8: 14-20.

90. Funde, S.T. (2005) Effect of Ocimum sanctum, Emblica officinalis and Levamisole on immune response in immunosuppressed broilers. Department of Veterinary medicine. Thesis submitted to Maharastra Animal and Fishery Science University, Nagpur.

91. Lanjewar, R.D., Zanzad, A.A., Ramteke, B.N. and Deshmukh, G.B. (2008) Effect of dietary supplementation of tulsi (O. sanctum) leaf powder on the growth performance and serum lipid profile in broilers. Indian Journal of Animal Nutrition., 25(4):395-97.

92. Varaprasad Reddy, L.S.S., Thangavel, A., Leela, V. and Narayana Raju, K.V.S. (2007) Effect of dietary supplementation of Tulsi (Ocimum sanctum) and Selenium on lipid peroxidation levels and growth rate in broiler chickens. Tamilnadu Journal of Veterinary and Animal Sciences., 3(3):144-49.

93. Gupta, G. and Charan, S. (2007) Exploring the potentials of Ocimum sanctum (Shyama tulsi) as a feed supplement for its growth promoter activity in broiler chickens. Indian Journal of Poultry Science., 42(2):140-43.

94. Mehala, C. and Moorthy, M. (2008b) Production performance of broilers fed with Aloe vera and Curcuma longa (Turmeric). International Journal of Poultry Science., 
7(9):852-56.

95. Tirupathi Reddy. (2010) Effect of herbal preparations on the performance of broilers. M.V.Sc., Thesis submitted to Sri Venkateswara Veterinary University, Tirupathi.

96. Kumari, P., Gupta, M.K., Ranjan. R., Singh, K.K. and Yadava, R. (1994) Curcuma longa as feed additive in broiler birds and its patho-physiological effects. National Toxicology Program Technical Report Series., 435:1-288.

97. Pande, C.B. (2000) Zeestress-A promising adaptogenic, antistress and immuno modulator - a review. Pashudan 15(12):4.

98. Sugiharto, I., Widiastuti, E. and Prabowo, N.S. (2011) Effect of turmeric extract on blood parameters, feed efficiency and abdominal fat content in broilers. $J$. IndonesianTrop.Anim.Agric., 36(1) : 21-26.

99. Basavaraj, M., Nagabhushana, V., Prakash, N., Mallikarjunappa, S., Appannavar, M.M. and Wagmare, P. (2010) Effect of dietary supplementation of Pulvis CurcumaLonga on the voluntary feed intake, nutrient digestibility and Growth performance of Broiler rabbits under summer stress. Vet. World., 3: 369-372.

100. Singh, N., Singh, J.P. and Singh, V. (2007) Effect of dietary supplementation of herbal formulation on dressing percentage and mortality in broiler chicks. Indian Journal of Field Veterinarians., 2:22-24.

101. Vidhyarthi, V.K., Nring, K. and Sharma, V.B. (2008) Effect of herbal growth promoters on the performance and economics of rearing broiler chicken. Indian Journal of Poultry Science., 43(3):297-300.

102. Emadi, M. and Kermanshahi, H. (2006). Effect of turmeric rhizome powder on performance and carcass characteristics of broiler chickens. International Journal of Poultry Science., 5:1069-1072.

103. Kurkure, N.V., Kalorey, D.R. and Ali, M.H. (2002). Herbal
Nutraceuticals: An alternative to antibiotic growth promoters. Poultry Fortune., 31-32.

104. Mehala, C. and Moorthy, M. (2008a) Effect of Aloe vera and Curcuma longa (Turmeric) on carcass characteristics and biochemical parameters of broilers. International Journal Poultry Science., 7(9):857-61.

105. Deshpande, R.R. (2006) Effect of dietary supplementation of Tulsi leaf powder (Ocimum sanctum) on egg yolk cholesterol and serum lipid profile in commercial layers. M.V.Sc. thesis submitted to Maharashtra Animal and Fishery Sciences University, Nagpur.

106. Emadi, M. and Kermanshahi, H. (2007b) Effect of turmeric rhizome powder on the activity of some blood enzymes in broiler chickens. International Journal of Poultry Science., 6:48-51.

107. Atul Prakash., Singh, S.P., Rachna, Varma., Choudary, G.K. and Ram, Sajan. (2009) Ameliorative efficacy of tulsi in Lead toxicity in cockerels. Indian Vet. J., 86:344-46.

108. Sapcota, D. and Upadhyaya, T.N. (2009) Efficacy of dietary Ocimum sanctum against Aflatoxin $\mathrm{B}_{1}$ in Broilers. Indian Veterinary Journal., 86:1163-65.

109. Emadi, M. and Kermanshahi, H. (2007a) Effect of turmeric rhizome powder on immunity responses of broiler chickens. Medwell Journal of Animal and Veterinary Advances., 6(7): 833-36.

110. Pande C B and Vijaykumar (1994) A study on immunomodulating action of Zeestress, Proc. Scientific symposium on recent advances in Veterinary Microbiology, B.C.K.V.V., Nadia, W.B, India.

111. Sawale, G.K., Gosh, R.C., Ravikanth, K., Maini, S. and Rekhe, D.S. (2009) Experimental mycotoxicosis in layer induced by ochratoxin A and it's amelioration with herbo mineral toxin binder "Toxiroak". Int. J. Poult. Sci., 8: 798803.

$* * * * * * * *$ 